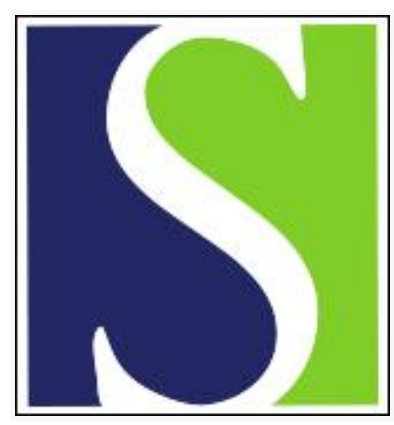

Scand J Work Environ Health 2004;30(2):139-148

https://doi.org/10.5271/sjweh.771

Issue date: Apr 2004

Impact of worktime arrangements on work-home interference among Dutch employees

by Jansen NWH, Kant I, Nijhuis FJN, Swaen GMH, Kristensen TS

Affiliation: Department of Epidemiology, Maastricht University, PO Box 616, 6200 MD Maastricht, The Netherlands. Nicole.Jansen@epid.unimaas.nl

Refers to the following texts of the Journal: 2001;27(2):97-105 1998;24(3):197-205

The following articles refer to this text: $2007 ; 33(2): 105-113 ;$ SJWEH Supplements 2008;(5):14-21; 2010;36(2):96-108; 2011;37(5):402-410; 2012;38(4):299-313; 2015;41(3):268-279; 2015;41(4):413-416; 2020;46(5):469-479

Key terms: employee; Netherlands; reciprocal effect; work schedule; work-family conflict; work-home interference; workhours; worktime

This article in PubMed: www.ncbi.nlm.nih.gov/pubmed/15143741 


\title{
Impact of worktime arrangements on work-home interference among Dutch employees
}

\author{
by Nicole WH Jansen, PhD, ${ }^{1}$ IJmert Kant, PhD, ${ }^{1}$ Frans JN Nijhuis, PhD, ${ }^{2}$ Gerard MH Swaen, PhD, ${ }^{1}$ Tage S \\ Kristensen, $P h D^{3}$
}

\begin{abstract}
Jansen NWH, Kant I, Nijhuis FJN, Swaen GMH, Kristensen TS. Impact of worktime arrangements on work-home interference among Dutch employees. Scand J Work Environ Health 2004;30(2):139-148.
\end{abstract}

\begin{abstract}
Objectives This study examined the effects of different worktime arrangements on work-home interference while taking into account other work-related factors, private situation and health status, explored gender differences in this relation, and examined reciprocal effects between workhours and work-home interference. Methods Data from the Maastricht cohort study on fatigue at work were used with 8 months of follow-up ( $\mathrm{N}=6947$ at baseline).

Results Worktime arrangements were related to work-home interference among the men and women, even after control for confounding. As compared with daywork, baseline shiftwork was associated with higher workhome interference over time. Within daywork, full-time work was prospectively related to higher work-home interference than part-time work was. For full-timers, baseline overtime work, hours of overtime work, change in number of workhours, and commuting time were related to higher work-home interference over time, whereas compensation for overtime work, familiarity with work roster, ability to take a day off, and a decrease in workhours at own request were associated with less work-home interference. For the part-timers, baseline overtime work and commuting time were related to higher work-home interference over time, whereas compensation for overtime, flexible workhours, and ability to take a day off were protective against work-home interference. Reciprocal relations between work-home interference and workhours were also found.

Conclusions Worktime arrangements are clearly related to work-home interference. Because reciprocal effects exist as well, important selection processes may exist. Nevertheless, specific characteristics of worktime arrangements could constitute useful tools for reducing work-home interference.
\end{abstract}

Key terms reciprocal effects, work-family conflict, workhours, work schedules.

Many employees are concerned about their ability to adequately combine their increasing demands at work and at home (1), and conflict between work and family is a salient issue nowadays. Work-family conflict is defined as a form of interrole conflict in which the role pressures from the work and family domains are mutually incompatible in some respect (2), where workers have insufficient energy or time or both to perform work and family roles successfully (3). Reported prevalences of work-family conflict range from about $10 \%$ (4) to about $41 \%(5,6)$. Conflict between work and family is mutual in nature $(7,8)$ in that work can interfere with family (work-home interference), for example, when family appointments have to be cancelled because of frequent overtime work, and family can interfere with work (home-work interference), for example, when workers have little energy at work because of high demands at home. Allen et al (8) noted important consequences associated with conflict from work on family, such as job dissatisfaction, job burnout, psychological distress, depression, and life and marital dissatisfaction. Work-family conflict has been reported to be a risk factor for an elevated need for recovery from work and fatigue as well (4). Several studies have reported gender differences with regard to the experience of work-family conflict (9-11).

At a time characterized by increasing numbers of dual-earner families and single-parents and the

1 Department of Epidemiology, Maastricht University, Maastricht, The Netherlands.

2 Department of Health Organization, Policy and Economics, Maastricht University, Maastricht, The Netherlands.

3 National Institute of Occupational Health, Copenhagen, Denmark.

Reprint requests to: Ms Nicole WH Jansen, Department of Epidemiology, Maastricht University, PO Box 616, 6200 MD Maastricht, The Netherlands. [E-mail: Nicole.Jansen@epid.unimaas.nl] 
evolving 24-hour society, there is a strong need for facilities that are better amenable to combining work and family. One starting point for these facilities can be found in worktime arrangements, because the amount of time demanded by work and the pattern and timing of work within the day constitute very obvious and important ways through which worklife affects family life (12). Moreover, worktime arrangements are dynamic and modifiable factors, because they can be subject to change. Studies have indeed reported that worktime is positively related to work interference with family or general work-family conflict $(11,13-15)$ and that long workhours may have negative consequences for employees who struggle to balance the demands of work and home life $(14,16)$. Because worktime arrangements are clearly work-related factors, in this study the direction of interference from work to home has been studied exclusively.

With regard to worktime arrangements, a distinction can be made between work schedules (shiftwork versus daywork) on one hand and actual workhours (full-time versus part-time) on the other. Shiftwork, as compared with daywork, has been reported to be a risk factor for general work-family conflict (4). For day workers specifically, subgroups can be defined with increased risks of work-home interference. One distinction can be made between full-time and part-time workers. The Netherlands is known for its high prevalence of part-time work. In $2000,18.9 \%$ of the male and $67.3 \%$ of the female active workforce worked less than 35 hours a week (17). Dutch women often change from full-time to part-time jobs or even leave the labor market altogether at one point during their career, especially following the birth of a first child, because of an incapability to combine work and family life adequately (18).

To structure the relationship between worktime arrangements and work-home interference, the conservation of resources (COR) theory $(19,20)$ could constitute an appropriate framework and has already been applied to work-family conflict in earlier studies $(3,4)$. The COR model proposes that people strive to obtain, retain, protect, and foster the things that they value. These valued entities are termed resources and include objects, conditions, personal characteristics, and energies $(20,21)$. According to the COR theory, psychological stress occurs when people are threatened with resource loss, lose resources, or fail to gain resources following resource investment (19). As more conflict or demands or both are experienced in one domain, fewer resources are available to fulfill one's role in another domain (3). For example, frequent overtime work may tap available resources and leave fewer resources available for family demands. In the case of frequent overtime work, work-home interference may be a reaction to a situation in which the resources of the employee are being threatened, depleted, or even lost because of the longer time spent at work and the prolonged effort investment. In line with the COR theory, other aspects of worktime arrangements, for example, those reflecting the control over and predictability of workhours, may add to employees' resources and constitute resource gains. We hypothesized that demanding characteristics of worktime arrangements, such as shiftwork and overtime work, would predict the onset of work-home interference over time, whereas supportive or facilitating elements, such as the ability to take a day off when wanted, would be protective against workhome interference.

Worktime arrangements are mainly structural components of work. Both structural and content components, such as job demands, are, however, critical to an understanding of the impact of work on employees and their families (22). Job demands often differ between shiftworkers and dayworkers (23-25) and between fulltimers and part-timers (26). Employees with longer workhours may experience more interference due to higher job demands than do those averaging fewer workhours. Because job demands are, in themselves, important factors affecting employees' resources, they should be controlled when effects of worktime arrangements on work-home interference are studied. The same goes for characteristics of the private situation, in which, for example, the degree of responsibility for child care or housekeeping may moderate the relationship between worktime arrangements and work-home interference. Furthermore, health status could be a potential confounder in the relation between worktime arrangements and work-home interference because, in line with the COR theory, health status can determine part of the energy levels, or resources, employees have left for juggling demands between work and family life.

It is likely that different components of worktime arrangements have a different time course of cause and effect. When the exposure is relatively stable over time, for example, in the case of shiftwork, both cross-sectional and longitudinal designs may be suitable. Crosssectional studies provide insight into the accumulated effects of worktime arrangements at the time of study and may reflect the length of exposure. Longitudinal studies, on the other hand, provide insight into the time sequence between worktime arrangements and the onset of work-home interference and study exposure before effect. Most studies so far have relied on cross-sectional associations between worktime arrangements and work-home interference. Both cross-sectional and longitudinal studies can be limited when it comes to selection effects and the impact of changes in exposure taking place before or during the time of study. Sometimes the effect may already be present at baseline. Finally, reciprocal effects may also occur, that is, employees 
experiencing high work-home interference may adjust their workhours over time as a means of reducing interference.

The current study was designed to expand the understanding of the role of worktime arrangements in work-home interference by using a cross-sectional and longitudinal design. The aims of this study were (i) to study the effects of various aspects of worktime arrangements on work-home interference, while taking into account work-related factors, characteristics of the private situation and health status, (ii) to explore gender differences in the relation between worktime arrangements and work-home interference, and (iii) to examine reciprocal effects between workhours and workhome interference.

\section{Participants and methods}

\section{Study population}

This study is based on data from the Maastricht cohort study on fatigue at work in the Dutch working population $(27,28)$. Employees were followed by means of nine consecutive self-administered questionnaires, which they received at four monthly intervals. In May 1998, a total of 26978 employees from 45 companies received a letter at home, inviting participation, and the self-administered baseline questionnaire. A reminder was sent out after 2 weeks. Altogether, 12161 employees completed and returned the baseline questionnaire (response rate of 45\%). Sixty-six questionnaires were excluded from the analysis due to technical reasons or because inclusion criteria were not met. The baseline $\left(\mathrm{T}_{0}\right)$ cohort consisted of $8840(73 \%)$ men and 3255 (27\%) women and captured both blue-collar and whitecollar workers. Detailed information on the sectors and trades represented in the Maastricht cohort study and on nonresponse has been reported elsewhere (25, 27).

The scale we used to measure work-home interference was first included at 24 months of follow-up $\left(\mathrm{T}_{6}\right.$, May 2000) and then again at 32 months of follow-up ( $\mathrm{T}_{8}$, January 2001), implying a period of 8 months' follow-up for the present study. At $\mathrm{T}_{6}$, the baseline measurement for the current study, the cohort consisted of 8007 employees, 5814 (72.6\%) men and 2193 (27.4\%) women. All employees who returned the questionnaire at $\mathrm{T}_{6}$ received the questionnaires at $\mathrm{T}_{7}$ (September 2000, response rate $63.3 \%, \mathrm{~N}=7662$ ) and $\mathrm{T}_{8}$ (January 2001, response rate $61.9 \%, \mathrm{~N}=7482$ ). In the analyses we excluded the employees who reported being absent from work due to illness or who reported working under modified conditions related to former sickness absence at the time of completing the questionnaire. These selection criteria resulted in a study population of 6947 employees, $5140(74 \%)$ men and 1807 (26\%) women, for the cross-sectional analyses on worktime arrangements and work-home interference at $\mathrm{T}_{6}$. For the analysis of prospective relationships between worktime arrangements and work-home interference after 8 months of followup, these selection criteria resulted in a study population of 5308 employees, $4033(76 \%)$ men and 1275 (24\%) women.

\section{Measures}

Work-home interference. To assess work-home interference, we used a shortened version (Cronbach's alpha 0.81 ) of the scale for work-home interference from the Survey Work-home Interference Nijmegen (SWING) $(29,30)$, a questionnaire designed to measure directions and domains of work-home interference. Examples of items are "How often do you have to cancel appointments with your partner, family or friends because of obligations at work?" and "How often do your workhours cause difficulties in meeting the demands at home?" All six items were scored on a four-point scale ranging from "seldom or never" to "very often". The total score on the scale for work-home interference ranged from 6 to 24. The upper tertile of the scale (total score $\geq 11$ ) was used to define the contrast between employees with high versus low-medium work-home interference.

Worktime arrangements. The questionnaire included 32 questions on worktime arrangements. Employees first provided information about the work schedule (daywork versus shiftwork). In this study the term shiftwork captures three-shift, four-shift, five-shift and irregular shiftwork, all including frequent night work. The employees also provided information on holding multiple jobs and workhours per week (recoded for $\geq 36$ hours, 26-35 hours, and $\leq 25$ hours), frequent overtime work, number of overtime hours a week, compensation for overtime (money, time, money and/or time, no compensation), flexible workhours, familiarity with work roster 1 month in advance, the ability to take a day off when wanted, whether employees had changed their workhours during the past year, and whether or not this change was at the workers' own request. Finally, commuting time to work ( $<30$ minutes, $\geq 30$ minutes) was queried. Except where otherwise noted, the response to each item was yes or no.

Work-related factors. A Dutch version of the Job Content Questionnaire was used to measure psychological job demands and decision latitude (31-33). Psychological job demands were assessed by the sum of five items 
(Cronbach's alpha 0.69). Decision latitude (Cronbach's alpha 0.81) was measured by the sum of the following two subscales: skill discretion and decision authority. The response options varied from "strongly disagree" to "strongly agree" on a four-point scale. Emotional demands at work were measured by the sum of five items, ranging from 0 to 5 (Cronbach's alpha 0.60 ). The questions were derived from a Dutch questionnaire on work and health (34), the Dutch Questionnaire on the Experience and Assessment of Work (35), and one self-formulated item. To assess whether employees perceived their work as physically demanding, one item of the Dutch questionnaire on work and health (VAG) (34) was used.

Private situation. Employees were asked if they had dependent children at home (yes;no) and about their

Table 1. Characteristics of the study population with regard to high work-home interference (upper tertile).

\begin{tabular}{|c|c|c|c|c|c|c|}
\hline \multirow[t]{2}{*}{ Characteristic } & \multicolumn{3}{|c|}{ Men } & \multicolumn{3}{|c|}{ Women } \\
\hline & $\begin{array}{c}\text { Total } \\
\text { number }\end{array}$ & $\begin{array}{l}\text { High } \\
\text { work- } \\
\text { home } \\
\text { inter- } \\
\text { ference } \\
(\%)\end{array}$ & $\begin{array}{c}\text { P- } \\
\text { value }\end{array}$ & $\begin{array}{c}\text { Total } \\
\text { number }\end{array}$ & $\begin{array}{l}\text { High } \\
\text { work- } \\
\text { home } \\
\text { inter- } \\
\text { ference } \\
(\%)\end{array}$ & $\begin{array}{c}\mathrm{P}- \\
\text { value }\end{array}$ \\
\hline Gender & 5140 & 35.8 & & 1807 & 28.2 & \\
\hline Age & & & $<0.0001$ & & & 0.114 \\
\hline$\leq 25$ years & 19 & 26.3 & & 42 & 26.2 & \\
\hline $26-35$ years & 777 & 37.7 & & 501 & 26.1 & \\
\hline $36-45$ years & 1869 & 39.5 & & 759 & 30.0 & \\
\hline $46-55$ years & 2011 & 33.6 & & 419 & 29.8 & \\
\hline$\geq 56$ years & 455 & 27.3 & & 80 & 17.5 & \\
\hline Workhours & & & 0.137 & & & $<0.0001$ \\
\hline $\begin{array}{l}\text { Low part-time } \\
\text { ( } \leq 25 \text { h/week) }\end{array}$ & 82 & 25.6 & & 785 & 21.1 & \\
\hline $\begin{array}{l}\text { High part-time } \\
(26-35 \text { h/week })\end{array}$ & 540 & 35.2 & & 405 & 32.1 & \\
\hline $\begin{array}{l}\text { Full-time } \\
\text { ( } \geq 36 \mathrm{~h} / \text { week) }\end{array}$ & 4489 & 36.1 & & 607 & 34.8 & \\
\hline $\begin{array}{l}\text { Frequent overtime } \\
\text { work }\end{array}$ & & & $<0.0001$ & & & $<0.0001$ \\
\hline Yes & 2261 & 49.7 & & 654 & 39.3 & \\
\hline No & 2834 & 24.8 & & 1139 & 21.7 & \\
\hline Work schedule & & & $<0.0001$ & & & $<0.0001$ \\
\hline Shiftwork & 1283 & 43.8 & & 337 & 36.2 & \\
\hline Daywork & 3766 & 33.0 & & 1408 & 26.1 & \\
\hline Multiple jobs & & & 0.347 & & & 0.236 \\
\hline Yes & 203 & 38.9 & & 79 & 34.2 & \\
\hline No & 4915 & 35.7 & & 1723 & 28.0 & \\
\hline Dependent childre & & & $<0.0001$ & & & 0.043 \\
\hline Yes & 2867 & 38.9 & & 886 & 30.4 & \\
\hline No & 2236 & 31.8 & & 909 & 26.1 & \\
\hline $\begin{array}{l}\text { Responsible for } \\
\text { housekeeping }\end{array}$ & & & 0.619 & & & 0.799 \\
\hline Yes, completely & 464 & 34.5 & & 884 & 28.2 & \\
\hline Yes, shared & 2427 & 36.4 & & 852 & 28.6 & \\
\hline No & 2208 & 35.3 & & 57 & 24.6 & \\
\hline
\end{tabular}

responsibility for housekeeping (coded as no; yes, shared; yes, completely).

Demographic and health-related factors. Employees provided information on gender, age, educational level, and presence of a long-term disease through self-report in the questionnaires.

\section{Statistical analysis}

Logistic regression analyses, stratified for gender, were conducted to study the cross-sectional relationship between worktime arrangements and work-home interference. The distribution of the scale for work-home interference was skewed to the left. Poisson regression analyses were conducted to study prospective relations between worktime arrangements at baseline and the continuous score of work-home interference at 8 months of follow-up. To study reciprocal effects, multivariate survival analyses using Cox regression were performed, in which we modeled the time to a change of workhours at $\mathrm{T}_{7}$ and $\mathrm{T}_{8}$. All the regression analyses were adjusted for age, presence of a long-term disease, educational level, psychological job demands, decision latitude, emotional and physical demands, dependent children, and housekeeping responsibility. Where the numbers of workers did not allow stratification for gender, we adjusted the regression analyses for gender as well. Other statistical procedures included chi-square tests and independent sample t-tests. Data were analyzed using SPSS for Windows release 11.0.1 (SPSS Inc, Chicago, IL, USA) and SAS release 8.02 (SAS Institute, Gary, NC, USA).

\section{Results}

As shown in table 1, work-home interference clearly differed across the demographic factors, worktime arrangements, and characteristics of the private situation. Employees reporting high work-home interference were more frequently male $(\mathrm{P}<0.0001)$. For both the men and the women, higher percentages of employees with elevated work-home interference were found among those aged 36-45 years, full-time workers, those with frequent overtime work, shift workers, and those with dependent children at home. Nonsignificant differences in work-home interference were observed between employees with different levels of housekeeping responsibility and between those with and without multiple jobs.

Logistic regression analyses showed that shift work was associated with higher work-home interference among the men [odds ratio (OR) 2.44, 95\% confidence 
interval (95\% CI) 1.98-3.00] and women (OR 2.14, 95\% CI 1.30-3.51) as compared with daywork. Employees with multiple jobs averaged 12.5 (SD 12.2) hours/week in the additional job. Holding multiple jobs was not, however, associated with more work-home interference among the men (OR 1.08, 95\% CI 0.77-1.50) or women (OR 1.14, 95\% CI 0.64-2.04). Similar findings were found in the Poisson regression analyses $(\mathrm{N}=5308)$, in which shiftwork at baseline was associated with somewhat higher work-home interference after 8 months of follow-up ( $\beta$ 0.129, SE 0.012, $\mathrm{P}<0.0001$ ), even when additionally adjusted for baseline work-home interference levels ( $\beta$ 0.048, SE 0.010, $\mathrm{P}<0.0001$ ).

All additional results for actual workhours, that is, full-time versus part-time work, and other characteristics related to workhours were based on the data of the dayworkers only, that is, we excluded the employees with multiple jobs, shiftworkers, and those involved in nightwork and evening work, the result being a study population of 4945 employees, 3606 (72.9\%) men and $1339(27.1 \%)$ women. For the men, we distinguished full-time ( $\geq 36$ hours/week) from part-time ( $<36$ hours/ week) work, whereas, for the women, the numbers allowed for distinguishing full-timers from low $(\leq 25$ hours/week) and high part-timers (26-35 hours/week). For the men, full-time work, as compared with part-time work, was not associated with higher work-home interference (OR 1.26, 95\% CI 0.87-1.82). For the women, a part-time job with a low number of hours (low parttime) protected against work-home interference (OR 0.29 , 95\% CI 0.19-0.44), whereas a job with a high number of hours (high part-time) was not associated with lower work-home interference (OR 0.71, 95\% CI 0.48-1.04) compared with full-time work.

Table 2 shows the cross-sectional associations between the characteristics of worktime arrangements and work-home interference for the male full-timers and part-timers separately. For the male full-timers, frequent overtime work, number of overtime hours, and an increase in workhours during the past year were associated with more work-home interference, whereas compensation for overtime, flexible workhours, familiarity with work roster in advance, and the ability to take a day off were associated with less work-home interference. In general, the associations between aspects of worktime arrangements and work-home interference were not as strong among the male part-timers, probably partly due to the smaller numbers of men working part-time.

Table 3 presents the cross-sectional associations between the characteristics of worktime arrangements and work-home interference for the women. For both the full-time and low part-time workers, overtime work was associated with more work-home interference. The number of overtime hours was associated with more work-home interference and familiarity with the work roster in advance with less work-home interference among the high part-time workers. A decrease in workhours was associated with more work-home interference for the full-time workers. High commuting time to work was associated with more work-home interference for the low part-time workers.

Table 2. Cross-sectional associations between worktime arrangements and work-home interference (upper tertile) among the men working full-time and part-time in day work. (OR = odds ratio, $95 \% \mathrm{Cl}=95 \%$ confidence interval)

\begin{tabular}{|c|c|c|c|c|}
\hline & \multicolumn{2}{|c|}{$\begin{array}{c}\text { Full-time work } \\
(\geq 36 \text { h/week) } \\
(\mathrm{N}=3402)\end{array}$} & \multicolumn{2}{|c|}{$\begin{array}{c}\text { Part-time work } \\
(<36 \mathrm{~h} / \text { week }) \\
(\mathrm{N}=204)\end{array}$} \\
\hline & $O R^{a}$ & $95 \% \mathrm{Cl}$ & $\mathrm{OR}^{\mathrm{a}}$ & $95 \% \mathrm{Cl}$ \\
\hline \multicolumn{5}{|c|}{ Frequent overtime work } \\
\hline Yes & 2.99 & $2.48-3.60$ & 2.36 & $0.99-5.60$ \\
\hline No & 1 & $\cdot$ & 1 & $\cdot$ \\
\hline \multicolumn{5}{|c|}{ Hours of overtime work a week } \\
\hline$<5$ & 1 & . & 1 & . \\
\hline$\geq 5$ & 2.17 & $1.73-2.71$ & 0.52 & $0.06-4.67$ \\
\hline \multicolumn{5}{|c|}{ Compensation for overtime hours } \\
\hline Time & 0.57 & $0.38-0.85$ & 0.46 & $0.07-3.12$ \\
\hline $\begin{array}{l}\text { Time or money } \\
\text { or both }\end{array}$ & 0.70 & $0.50-0.97$ & 0.11 & $0.05-2.46$ \\
\hline Money & 0.46 & $0.27-0.77$ &..$b$ &.. \\
\hline No & 1 & $\cdot$ & 1 & $\cdot$ \\
\hline \multicolumn{5}{|l|}{ Flexible workhours } \\
\hline Yes & 0.82 & $0.68-0.98$ & 1.06 & $0.67-1.67$ \\
\hline No & 1 & $\cdot$ & 1 & $\cdot$ \\
\hline \multicolumn{5}{|c|}{$\begin{array}{l}\text { Work roster known } 1 \text { month } \\
\text { in advance }\end{array}$} \\
\hline Yes & 0.62 & $0.51-0.76$ & 0.61 & $0.22-1.73$ \\
\hline No & 1 & $\cdot$ & 1 & $\cdot$ \\
\hline \multicolumn{5}{|c|}{$\begin{array}{l}\text { Able to take a day off when } \\
\text { wanted }\end{array}$} \\
\hline Yes & 0.45 & $0.35-0.58$ & 0.97 & $0.33-2.82$ \\
\hline No & 1 & $\cdot$ & 1 & $\cdot$ \\
\hline \multicolumn{5}{|c|}{ Decrease in workhours } \\
\hline Yes & 1.12 & $0.68-1.83$ & 0.38 & $0.13-1.14$ \\
\hline No & 1 & . & 1 & $\cdot$ \\
\hline \multicolumn{5}{|c|}{$\begin{array}{l}\text { Decrease in workhours at } \\
\text { own request }\end{array}$} \\
\hline Yes & 0.37 & $0.10-1.43$ & . & . \\
\hline No & 1 & $\cdot$ &..$b$ &.$\cdot$ \\
\hline \multicolumn{5}{|c|}{ Increase in workhours } \\
\hline Yes & 2.17 & $1.66-2.82$ & 2.25 & $0.40-12.65$ \\
\hline No & 1 & $\cdot$ & 1 & $\cdot$ \\
\hline \multicolumn{5}{|c|}{$\begin{array}{l}\text { Increase in workhours at } \\
\text { own request }\end{array}$} \\
\hline Yes & 0.92 & $0.51-1.66$ & . & . \\
\hline No & 1 & $\cdot$ &..$b$ & .. \\
\hline \multicolumn{5}{|c|}{ Commuting time to work } \\
\hline$<30$ minutes & 1 & . & 1 & . \\
\hline$\geq 30$ minutes & 1.00 & $0.84-1.19$ & 1.16 & $0.51-2.64$ \\
\hline
\end{tabular}

a Adjusted for age, presence of a long-term disease, educational level, psychological job demands, decision latitude, emotional and physical demands, dependent children, and responsibility for housekeeping. b Data not available, because the sample size was too small. 
Table 3. Cross-sectional associations between worktime arrangements and work-home interference (upper tertile) among the women working full-time, high part-time, and low part-time schedules in daywork. (OR $=$ odds ratio, $95 \% \mathrm{Cl}=95 \%$ confidence interval)

\begin{tabular}{|c|c|c|c|c|c|c|}
\hline & \multicolumn{2}{|c|}{$\begin{array}{c}\text { Full-time } \\
\text { work } \\
(\geq 36 \mathrm{~h} / \text { week) } \\
(\mathrm{N}=494)\end{array}$} & \multicolumn{2}{|c|}{$\begin{array}{c}\text { High part- } \\
\text { time work } \\
(26-35 \mathrm{~h} / \text { week }) \\
(\mathrm{N}=286)\end{array}$} & \multicolumn{2}{|c|}{$\begin{array}{c}\text { Low part- } \\
\text { time work } \\
(\leq 25 \mathrm{~h} / \text { week }) \\
(\mathrm{N}=559)\end{array}$} \\
\hline & $\mathrm{OR}^{\mathrm{a}}$ & $95 \% \mathrm{Cl}$ & $\mathrm{OR}^{\mathrm{a}}$ & $95 \% \mathrm{Cl}$ & $\mathrm{OR}^{\mathrm{a}}$ & $95 \% \mathrm{Cl}$ \\
\hline \multicolumn{7}{|l|}{$\begin{array}{l}\text { Frequent over- } \\
\text { time work }\end{array}$} \\
\hline $\begin{array}{l}\text { Yes } \\
\text { No }\end{array}$ & $\begin{array}{c}1.89 \\
1\end{array}$ & $\begin{array}{c}1.12-3.19 \\
\cdot\end{array}$ & $\begin{array}{c}1.72 \\
1\end{array}$ & $\begin{array}{c}0.88-3.35 \\
\cdot\end{array}$ & $\begin{array}{c}1.96 \\
1\end{array}$ & $\begin{array}{c}1.16-3.33 \\
\cdot\end{array}$ \\
\hline \multicolumn{7}{|c|}{$\begin{array}{l}\text { Hours of over- } \\
\text { time work a week }\end{array}$} \\
\hline $\begin{array}{l}<5 \\
\geq 5\end{array}$ & $\begin{array}{c}1 \\
1.78\end{array}$ & $0.88-3.60$ & $\begin{array}{c}1 \\
4.30\end{array}$ & $1.34-13.84$ & $\begin{array}{c}1 \\
2.27\end{array}$ & $0.72-7.12$ \\
\hline \multicolumn{7}{|c|}{$\begin{array}{l}\text { Compensation for } \\
\text { overtime hours }\end{array}$} \\
\hline $\begin{array}{l}\text { Time } \\
\text { Time or mone }\end{array}$ & & $0.29-1.91$ & 0.35 & $0.10-1.23$ & 1.28 & $0.40-4.13$ \\
\hline $\begin{array}{l}\text { or both } \\
\text { Money }\end{array}$ & $\begin{array}{l}0.92 \\
2.42\end{array}$ & $\begin{array}{c}0.31-2.74 \\
0.44-13.26\end{array}$ & $\begin{array}{l}0.33 \\
0.40\end{array}$ & $\begin{array}{l}0.05-2.04 \\
0.04-4.56\end{array}$ & $\begin{array}{l}0.42 \\
1.67\end{array}$ & $\begin{array}{l}0.10-1.69 \\
0.32-8.70\end{array}$ \\
\hline No & 1 & . & 1 & . & 1 & . \\
\hline \multicolumn{7}{|l|}{$\begin{array}{l}\text { Flexible work- } \\
\text { hours }\end{array}$} \\
\hline $\begin{array}{l}\text { Yes } \\
\text { No }\end{array}$ & $\begin{array}{c}1.40 \\
1\end{array}$ & $\begin{array}{c}0.97-2.03 \\
\cdot\end{array}$ & $\begin{array}{c}0.63 \\
1\end{array}$ & $\begin{array}{c}0.34-1.19 \\
\cdot\end{array}$ & $\begin{array}{c}0.97 \\
1\end{array}$ & $\begin{array}{c}0.64-1.47 \\
\cdot\end{array}$ \\
\hline \multicolumn{7}{|c|}{$\begin{array}{l}\text { Work roster } \\
\text { known } 1 \text { month } \\
\text { in advance }\end{array}$} \\
\hline $\begin{array}{l}\text { Yes } \\
\text { No }\end{array}$ & $\begin{array}{c}0.54 \\
1\end{array}$ & $\begin{array}{c}0.26-1.14 \\
\cdot\end{array}$ & $\begin{array}{c}0.43 \\
1\end{array}$ & $\begin{array}{c}0.19-0.99 \\
.\end{array}$ & $\begin{array}{c}0.71 \\
1\end{array}$ & $\begin{array}{c}0.32-1.59 \\
.\end{array}$ \\
\hline \multicolumn{7}{|l|}{$\begin{array}{l}\text { Able to take } \\
\text { a day off when } \\
\text { wanted }\end{array}$} \\
\hline $\begin{array}{l}\text { Yes } \\
\text { No }\end{array}$ & $\begin{array}{c}0.85 \\
1\end{array}$ & $\begin{array}{c}0.47-1.54 \\
\cdot\end{array}$ & $\begin{array}{c}0.51 \\
1\end{array}$ & $\begin{array}{c}0.24-1.08 \\
\cdot\end{array}$ & $\begin{array}{c}0.84 \\
1\end{array}$ & $\begin{array}{c}0.47-1.49 \\
.\end{array}$ \\
\hline \multicolumn{7}{|l|}{$\begin{array}{l}\text { Decrease in } \\
\text { workhours }\end{array}$} \\
\hline $\begin{array}{l}\text { Yes } \\
\text { No }\end{array}$ & $\begin{array}{c}4.92 \\
1\end{array}$ & $\begin{array}{c}1.40-17.23 \\
\cdot\end{array}$ & $\begin{array}{c}0.99 \\
1\end{array}$ & $\begin{array}{c}0.44-2.25 \\
\cdot\end{array}$ & $\begin{array}{c}0.59 \\
1\end{array}$ & $\begin{array}{c}0.24-1.45 \\
.\end{array}$ \\
\hline \multicolumn{7}{|l|}{$\begin{array}{l}\text { Increase in } \\
\text { workhours }\end{array}$} \\
\hline $\begin{array}{l}\text { Yes } \\
\text { No }\end{array}$ & $\begin{array}{c}1.52 \\
1\end{array}$ & $\begin{array}{c}0.75-3.06 \\
\cdot\end{array}$ & $\begin{array}{c}1.04 \\
1\end{array}$ & $\begin{array}{c}0.44-2.45 \\
.\end{array}$ & $\begin{array}{c}1.30 \\
1\end{array}$ & $\begin{array}{c}0.61-2.77 \\
.\end{array}$ \\
\hline \multicolumn{7}{|c|}{$\begin{array}{l}\text { Commuting time } \\
\text { to work }\end{array}$} \\
\hline $\begin{array}{l}<30 \text { minutes } \\
\geq 30 \text { minutes }\end{array}$ & $\begin{array}{c}1 \\
1.38\end{array}$ & $\underset{0.83-2.31}{\cdot}$ & $\begin{array}{c}1 \\
1.23\end{array}$ & 0.61-2.46 & $\begin{array}{c}1 \\
2.83\end{array}$ & $\begin{array}{c}\cdot .54-5.20 \\
.\end{array}$ \\
\hline
\end{tabular}

a Adjusted for age, presence of a long-term disease, educational level, psychological job demands, decision latitude, emotional and physical demands, responsibility for housekeeping, and dependent children.

A Poisson regression analysis was conducted to study the prospective relationship between worktime arrangements at baseline and the continuous score of work-home interference after 8 months of follow-up among the dayworkers (table 4). Excluded were employees who had multiple jobs or who were involved in shiftwork, evening work, or nightwork at $\mathrm{T}_{6}$, the result being a study population of 4336 employees, 3193 (73.6\%) men and 1143 (26.4\%) women, with 8 months of follow-up. These analyses were performed without stratification for gender because such stratification would have resulted in numbers that were too low. Baseline full-time work was associated with higher workhome interference after 8 months of follow-up. Additional adjustments for the baseline work-home interference levels revealed less strong associations. For fulltime workers specifically, all the characteristics of the worktime arrangements, except for flexible workhours and an increase in workhours at the worker's own request, were associated with work-home interference. When additional adjustments for baseline work-home interference were made, the associations were not as strong. For part-timers, frequent overtime work and high commuting time to work at baseline were associated with more work-home interference after 8 months of follow-up, whereas compensation for overtime, flexible workhours, and the ability to take a day off when wanted were associated with less work-home interference. After additional adjustment for baseline work-home interference, overtime work was still associated with more work-home interference, whereas the ability to take a day off when wanted and increased workhours per week during the past year were associated with less workhome interference.

To test whether the findings remained similar when the different characteristics of worktime arrangements were included altogether in the Poisson regression analyses, we constructed a multivariate model with full-time versus part-time work, overtime work, flexible workhours, commuting time, familiarity with work roster, ability to take a day off, age, gender, presence of a long-term disease, educational level, psychological job demands, decision latitude, physical and emotional demands, responsibility for housekeeping, and dependent children. This model revealed that, for the characteristics of the baseline worktime arrangements, full-time work $(\mathrm{P}<0.01)$, overtime work $(\mathrm{P}<0.0001), \geq 30$ minutes' commuting time to work $(\mathrm{P}<0.0001)$, familiarity with work roster in advance $(\mathrm{P}<0.0001)$, and the ability to take a day off when wanted $(\mathrm{P}<0.0001)$ still remained associated with work-home interference in the expected direction after 8 months of follow-up. When additionally controlled for baseline work-home interference, only overtime work $(\mathrm{P}<0.0001)$ remained associated with work-home interference.

To study reciprocal effects between workhours and work-home interference, we examined whether high work-home interference (upper tertile) at $\mathrm{T}_{6}$ among fulltime workers ( $\geq 36$ hour/week) predicted a change in workhours over 8 months of follow-up. Cox regression analyses were performed in which we modeled the time to a change of workhours at $\mathrm{T}_{7}$ and $\mathrm{T}_{8}$. Employees 
Table 4. Baseline worktime arrangements as risk factors for work-home interference (continuous score) after 8 months of follow-up among the dayworkers. ${ }^{a}$

\begin{tabular}{|c|c|c|c|c|c|c|c|c|c|c|c|c|}
\hline & \multicolumn{6}{|c|}{ Full-time work ( $\geq 36 \mathrm{~h} /$ week) ( $\mathrm{N}=3422)$} & \multicolumn{6}{|c|}{ Part-time work (<36 h/week) (N=914) } \\
\hline & \multicolumn{3}{|c|}{ Model $1^{\mathrm{b}}$} & \multicolumn{3}{|c|}{ Model $2^{c}$} & \multicolumn{3}{|c|}{ Model $1^{b}$} & \multicolumn{3}{|c|}{ Model $2^{c}$} \\
\hline & $\beta$ & SE & P-value & $\beta$ & SE & P-value & $\beta$ & SE & P-value & $\beta$ & SE & P-value \\
\hline Frequent overtime work & 0.126 & 0.011 & $<0.0001$ & 0.039 & 0.009 & $<0.0001$ & 0.140 & 0.021 & & 0.071 & 0.017 & $<0.0001$ \\
\hline$\geq 5$ hours of overtime work a week & 0.030 & 0.009 & 0.001 & 0.004 & 0.008 & & 0.067 & 0.041 & 0.100 & 0.014 & 0.034 & 0.688 \\
\hline Overtime hours compensated & -0.064 & 0.018 & $<0.0001$ & -0.017 & 0.014 & 0.247 & -0.088 & 0.042 & 0.035 & -0.037 & 0.035 & 0.287 \\
\hline Flexible workhours & -0.001 & 0.009 & 0.939 & 0.006 & 0.007 & 0.438 & -0.030 & 0.015 & 0.047 & -0.020 & 0.012 & 0.088 \\
\hline Work roster known 1 month in advance & -0.059 & 0.013 & $<0.0001$ & -0.009 & 0.010 & 0.374 & -0.049 & 0.027 & 0.075 & 0.009 & 0.022 & 0.676 \\
\hline Able to take a day off when wanted & -0.068 & 0.015 & $<0.0001$ & -0.012 & 0.012 & 0.313 & -0.095 & 0.024 & $<0.0001$ & -0.040 & 0.019 & 0.033 \\
\hline Decrease in workhours & 0.067 & 0.029 & 0.022 & 0.046 & 0.023 & 0.047 & -0.004 & 0.028 & 0.889 & 0.009 & 0.022 & 0.676 \\
\hline Decrease in workhours at own request & -0.152 & 0.073 & 0.038 & -0.062 & 0.063 & 0.320 & -0.077 & 0.105 & 0.460 & -0.160 & 0.097 & 0.099 \\
\hline Increase in workhours & 0.083 & 0.016 & $<0.0001$ & 0.018 & 0.012 & 0.145 & -0.001 & 0.032 & 0.973 & -0.056 & 0.025 & 0.027 \\
\hline Increase in workhours at own request & -0.012 & 0.037 & 0.751 & 0.013 & 0.029 & 0.668 & -0.047 & 0.073 & 0.518 & 0.006 & 0.065 & 0.924 \\
\hline$\geq 30$ minutes commuting time to work & 0.033 & 0.010 & 0.001 & 0.011 & 0.008 & 0.178 & 0.064 & 0.023 & 0.005 & 0.019 & 0.018 & 0.301 \\
\hline
\end{tabular}

a Full-time versus part-time day work: model 1: $\beta 0.059$ (SE 0.015), P-value <0.0001; model 2: $\beta 0.015$ (SE 0.011), P-value 0.180.

${ }^{b}$ Adjusted for gender, age, presence of a long-term disease, educational level, psychological job demands, decision latitude, emotional and physical demands, responsibility for housekeeping, and dependent children.

${ }^{c}$ Additionally adjusted for continuous baseline work-home interference levels.

involved in shiftwork or in multiple jobs or both and those who reported themselves absent from work due to illness or reported work under modified conditions related to former sickness absence at $\mathrm{T}_{6}$ were excluded, the result being $\mathrm{N}=3828$. We were unable to study whether the change in workhours at $\mathrm{T}_{7}$ or $\mathrm{T}_{8}$ was an increase or decrease in workhours. Therefore, we studied full-time workers exclusively, for whom a change of workhours over time most likely reflects a decrease in hours. Multivariate Cox regression analyses showed that high baseline work-home interference was associated with an increased probability of changing workhours over time both for the men (RR 1.36, 95\% CI 1.08-1.72) and for the women (RR 2.04, 95\% CI 1.18-3.52).

\section{Discussion}

Worktime arrangements were clearly related to workhome interference both in the cross-sectional and in the longitudinal analyses, differences emerging between the men and the women, between day- and shiftworkers, and between full-timers and part-timers. These differences remained even after adjustment for work-related factors, characteristics of the private situation and health status and therefore provides evidence of true prospective relations between worktime arrangements and work-home interference. Adjustments for these factors showed a large impact on the relation between worktime arrangements and work-home interference and points to the necessity of taking job content, private situations, and health status into account in this area of research. This finding is fully in agreement with the propositions of the COR theory. Furthermore, reciprocal effects between workhours and work-home interference were observed. Shiftwork was a risk factor for work-home interference after 8 months of follow-up. Because shiftwork involves working and living patterns diverging from community rhythms of social, recreational, and domestic activities $(36,37)$, conflict between work and family would be more likely to arise among shiftworkers than among dayworkers. Holding multiple jobs, in contrast, was not related to higher work-home interference. An explanation could be that having multiple jobs actually represents a very crude measure, due to the fact that the group of employees with multiple jobs can consist of workers with very different workhours and job content in the additional job. Another explanation is that selection took place in which only those who were better able to combine work and family life held multiple jobs.

An adequate comparison of the results regarding the effects of full-time and part-time work on work-home interference with other studies is difficult or sometimes hindered because of the different definitions and operationalizations used for workhours and work-home interference. Full-time work was prospectively related to higher work-home interference than part-time work was. Although other studies have also found long workhours to be associated with work-home interference or general work-family conflict $(11,13-15)$, we were able to study specific aspects of worktime arrangements in relation to work-home interference. For the full-timers, overtime work was prospectively related to higher work-home interference. Prolongation of the workday could, in line with the COR theory, deplete the time or energy or both available for family activities, a 
finding also of the cross-sectional analyses, in which, particularly for the women with a low part-time job, overtime work, and high commuting time fostered work-home interference. Possibly, these women had already anticipated work-home interference and selected part-time work as an option to reduce it. Due to the prolonged workday, their carefully selected fit between work and family was compromised, and work-home interference became more likely to develop.

Both an increase and decrease in workhours during the past year was related to higher work-home interference among full-time workers in the prospective analyses. Possible explanations could be that the employees who changed their workhours had not yet adapted to their new workhours or that the change in workhours was still not enough to combine work and family life adequately. Furthermore, the private situation may have become more demanding for employees who had started working fewer hours during the past year. When we specifically studied whether or not the change in hours was the worker's own choice, it was found that working fewer hours at one's own request during the past year was prospectively related to less work-home interference among the full-time workers. The opportunity to take a day off when wanted, indicating autonomy or control over workhours, could provide employees with more possibilities to combine work and family life and was, in line with our hypotheses, found to be protective against work-home interference. Flexible workhours were not consistently associated with less work-home interference. In a study by Smith Major et al (14), the relation between long workhours and timebased work interference with family was not moderated by schedule flexibility as well. One explanation could be that flexible workhours do not provide a solution for employees with structural time conflicts between work and family, because the actual hours that need to be spent at work still remain similar. Flexible hours may provide a solution when employees encounter occasional time conflict situations however.

Several methodological and conceptual issues should be addressed in our study. A first issue concerns the time window of relations between worktime arrangements and work-home interference. Both the cross-sectional and longitudinal analyses yielded significant associations with work-home interference. From the prospective analyses it appears, however, that worktime arrangements do not necessarily have an immediate effect on work-home interference, but may also develop gradually. In this study we used an 8-month follow-up period. Although worktime arrangements were clear risk factors for work-home interference after 8 months of follow-up, it is likely that different aspects of worktime arrangements, such as shiftwork or overtime work, may have a different time course of cause and effect. In our study, for shift workers a steady-state situation may have already been developed with regard to work-home interference. Still, significant effects of shiftwork were observed that could also be due to changes in the work or home situation that we did not control for. For future research it is valuable to study different time windows for the relationship between worktime arrangements and work-home interference. Second, the employees in our study were already in the middle of an ongoing process with regard to both worktime arrangements and combining work and family. In this respect, the term baseline is not a true reference condition because employees experiencing work-home interference may have already chosen daywork instead of shiftwork, or part-time work and less overtime work, as an option to reduce work-home interference. The reciprocal effects between work-home interference and workhours clearly pointed in this direction. Consequently, a selection bias may have taken place before our baseline measurements or during the follow-up or both and, therefore, reduced all the observed associations. This could also be an explanation for the lower proportion of women reporting work-home interference, because it could be argued that this selection may be stronger among women, since women have culturally accepted ways of coping with work-home interference, for example, working parttime as an option that permits more time for their families. Compared with women in other European countries, Dutch women are less inclined to entrust a great part of child care to someone outside of the household, and, as a consequence, their situation in the labor market is usually adapted to the situation at home (38). Indeed, we observed that full-time working women with high work-home interference had a substantially higher probability of changing their workhours over time, compared with those reporting lower work-home interference. For men, similar findings were observed, although the associations were not as strong. Third, from a methodological point of view, it was important to exclude employees absent from work at the time of completing the questionnaires, because these employees might have interpreted the questions on combining work and family differently. However, excluding employees absent from work may have resulted in an underestimation of risks, because these employees could be more likely to stay away from work due to problems in combining work and family. Fourth, in this study, we used self-reported data only, although the measurement of worktime arrangements can be considered fairly objective. Nevertheless, common method variance may have caused an overestimation of the strength of the observed associations between worktime arrangements and workhome interference. Finally, to date, there are no existing cutoff points for classifying employees with marked work-home interference as measured with SWING. 
Therefore, in this study, we used the upper tertile to define a contrast between employees with and without marked work-home interference. It should be kept in mind that using this upper tertile actually reflects a moderate contrast only, since the work-home interference scale was skewed to the left.

From our present study, we conclude that worktime arrangements may have both beneficial and adverse effects on work-home interference under certain specific conditions. Demanding aspects of worktime arrangements, such as overtime work and shift work, were associated with higher work-home interference, whereas characteristics of worktime arrangements reflecting control and predictability were protective against workhome interference. Because worktime arrangements are, in essence, dynamic and modifiable factors that can be subject to change when necessary or requested, they constitute important tools for reducing work-home interference. Furthermore, high work-home interference at baseline was an important predictor for changing workhours over time. This finding further points to the importance of worktime arrangements for an adequate work-family balance, not only on an individual level, but also on a societal level with respect to consequences of work-home interference in terms of labor force participation.

\section{Acknowledgments}

The Maastricht cohort study is part of The Netherlands concerted research action on fatigue at work granted by The Netherlands Organization for Scientific Research. Our present study was supported by grant 580-02.201 from The Netherlands Organization for Scientific Research.

\section{References}

1. Ester P, Vinken H. Van later zorg: verwachtingen van Nederlanders over arbeid, zorg en vrijetijd in de 21e eeuw [Of later concern: expectations of the Dutch population about work, care, and leisure in the 21st century]. Den Haag: Service Centrum Uitgevers; 2000.

2. Greenhaus JH, Beutell NJ. Sources and conflict between work and family roles. Acad Manage Rev 1985;10(1):76-88.

3. Grandey AA, Cropanzano R. The Conservation Of Resources model applied to work-family conflict and strain. J Vocat Behav 1999;54:350-70.

4. Jansen NWH, Kant IJ, Kristensen TS, Nijhuis FJN. Antecedents and consequences of work-family conflict: a prospective cohort study. J Occup Environ Med 2003;45:479-91.

5. Frone MR, Russell M, Cooper ML. Prevalence of workfamily conflict: are work and family boundaries asymmetri- cally permeable? J Organ Behav 1992;13:723-9.

6. Kinnunen U, Mauno S. Antecedents and outcomes of workfamily conflict among employed women and men in Finland. Hum Relat 1998;51:157-77.

7. Frone MR, Russell M, Cooper ML. Antecedents and outcomes of work-family conflict: testing a model of the workfamily interface. J Appl Psychol 1992;77:65-78.

8. Allen TD, Herst DEL, Bruck CS, Sutton M. Consequences associated with work-to-family conflict: a review and agenda for future research. J Occup Health Psychol 2000;5:278-308.

9. Duxbury LE, Higgins CA. Gender differences in work-family conflict. J Appl Psychol 1991;76:60-73.

10. Eckenrode J, Gore S. Stress and coping at the boundary of work and family. In: Eckenrode J, Gore S, editors. Stress between work and family. New York (NY): Plenum; 1990. p $1-16$.

11. Gutek BA, Searle S, Klepa L. Rational versus gender role explanations for work-family conflict. J Appl Psychol 1991;76:560-8

12. Kanter RM. Work and family in the United States: a critical review and agenda for research and policy. New York (NY): Russell Sage Foundation, Social Science Frontiers; 1977.

13. Grzywacz JG, Marks NF. Reconceptualizing the work-family interface: an ecological perspective on the correlates of positive and negative spillover between work and family. J Occup Health Psychol 2000;5:111-26.

14. Smith Major V, Klein KJ, Ehrhart MG. Work time, work interference with family, and psychological distress. J Appl Psychol 2002;87:427-36.

15. O'Driscoll MP, Ilgen DR, Hildreth K. Time devoted to job and off-job activities, interrole conflict, and affective experiences. J Appl Psychol 1992;77:272-9.

16. Hochschild AR. The time bind: when work becomes home and home becomes work. New York (NY): Metropolitan Books; 1997.

17. Central Bureau of Statistics. Statistisch Jaarboek 2003 [Statistical yearbook 2003]. Voorburg/Heerlen (The Netherlands): Centraal Bureau voor de Statistiek; 2003.

18. Koopmans I, Stavenuiter MMJ. Meer werken, minder zorgen: arbeid en zorg in wetgeving en CAO's [More working, less caring: work and care in legislation and collective labor agreements]. Breukelen (The Netherlands): NYFER; 1999.

19. Hobfoll SE. Conservation of resources: a new attempt at conceptualizing stress. Am Psychol 1989;44:513-24.

20. Hobfoll SE, Shirom A. Conservation of resources theory: applications to stress and management in the workplace. In: Golembiewski RT, editor. Handbook of organizational behavior. New York (NY): Dekker; 2001. p 57-80.

21. Hobfoll SE. The influence of culture, community, and the nested-self in the stress process: advancing conservation of resources theory. Appl Psychol Int Rev 2001;50:337-70.

22. Barnett RC. Toward a review and reconceptualization of the work/family literature. Genet Soc Gen Psychol Monograph 1998;124:125-82.

23. Bøggild H, Burr H, Tüchsen F, Jeppesen HJ. Work environment of Danish shift and day workers. Scand J Work Environ Health 2001;27(2):97-105.

24. Jansen NWH, Kant IJ, Van Amelsvoort LPGM, Nijhuis FJN, Van den Brandt PA. Need for recovery from work: evaluating short-term effects of working hours, patterns and schedules. Ergonomics 2003;46:664-80.

25. Jansen NWH, Van Amelsvoort LPGM, Kristensen TS, Van den Brandt PA, Kant IJ. Work schedules and fatigue: a prospective cohort study. Occup Environ Med 2003;60 Suppl 
$1: i 47-53$.

26. Barnett RC, Gareis KC. Reduced-hours employment: the relationship between difficulty of trade-offs and quality of life. Work Occup 2000;27:168-87.

27. Kant IJ, Bültmann U, Schröer CAP, Beurskens AJHM, Van Amelsvoort LPGM, Swaen GMH. An epidemiological approach to study fatigue in the working population: The Maastricht Cohort Study. Occup Environ Med 2003;60 Suppl 1:i32-9.

28. Kant IJ, Beurskens AJHM, Schröer CAP, Nijhuis FJN, Van Schayck CP, Van den Elzen HJ, et al. De Maastrichtse Cohort Studie naar langdurige psychische vermoeidheid in de arbeidssituatie [The Maastricht Cohort Study on fatigue at work]. Tijdschr Bedr Verzekeringsgeneesk 2000;8:226-32.

29. Wagena E, Geurts S. SWING: ontwikkeling en validering van de 'Survey Werk-thuis Interferentie-Nijmegen' [SWING: development and validation of the 'Survey Work-home Interference Nijmegen']. Gedrag Gezondheid 2000;28:138-57.

30. Van der Hulst M, Geurts S. Associations between overtime and psychological health in high and low reward jobs. Work Stress 2001;15:227-40.

31. Houtman I. Reliability and validity of the Dutch version of the Karasek Job Content Questionnaire. Presented at the NIOSH/APA conference on stress, work, and health in Washington (DC) in 1995.

32. Karasek RA. The Job Content Questionnaire and User's Guide (version 1.1). Los Angeles (CA): Department of In- dustrial and Systems Engineering, University of Southern California; 1985.

33. Niedhammer I, Goldberg M, Leclerc A, Bugel I, David S. Psychosocial factors at work and subsequent depressive symptoms in the Gazel cohort. Scand J Work Environ Health 1998;24(3):197-205.

34. Gründemann RWM, Smulders PWG, De Winter CR. Handleiding: vragenlijst arbeid en gezondheid [Manual: questionnaire on work and health]. Lisse (The Netherlands): Swets \& Zeitlinger; 1993.

35. Van Veldhoven M, Meijman TF. Het meten van psychosociale arbeidsbelasting met een vragenlijst: de vragenlijst beleving en beoordeling van de arbeid (VBBA) [The measurement of psychosocial job demands with a questionnaire (VBBA)]. Amsterdam: Nederlands Instituut voor Arbeidsomstandighten; 1994.

36. Loudoun RJ, Bohle PL. Work/non-work conflict and health in shiftwork: relationships with family status and social support. Int J Occup Environ Health 1997;3 Suppl 2 :S71-7.

37. Walker J. Social problems of shiftwork. In: Folkard S, Monk $\mathrm{TH}$, editors. Hours of work: temporal factors in work-scheduling. New York (NY): John Wiley \& Sons; 1985. p 211-25.

38. Fokkema T. Combining a job and children: contrasting the health of married and divorced women in the Netherlands? Soc Sci Med 2002;54:741-52.

Received for publication: 1 April 2003 